\title{
PENGEMBANGAN BIOGAS KOTORAN SAPI DI KEL. KEDOPOK KEC. KEDOPOK PROBOLINGGO
}

\author{
Taqijjuddin Alawy ${ }^{1}$, Istirochah Pujiwati ${ }^{2}$ \\ ${ }^{1}$ Fakultas Teknik Universitas Islam Malang \\ email: taqiijuddin alawy@unisma.ac.id \\ ${ }^{2}$ Fakultas Pertanian Universitas Islam Malang \\ email: istirochah@unisma.ac.id
}

\begin{abstract}
ABSTRAK
Warga kelurahan Kedopok kec. Kedopok Probolinggo telah lama membudidayakan ternak sapi potong yang dilakukan secara berkelompok. Keberadaan kelompok peternak sapi ini telah mendapatkan dukungan usaha dari dinas peternakan setempat dan pemda Probolinggo namun dirasakan peternak masih kurang karena beberapa sarana penting belum dimiliki diantaranya instalasi biogas.Pekerjaan utama dari peternak adalah petani atau buruh tani dengan pekerjaan sampingan sebagai peternak sapi. Rata-rata tiap peternak memiliki 2-3 ekor sapi yang dikumpulkan jadi 1 kandang milik bersama dan dikelola bersama baik masalah pakan, pengelolaan kandang, bibit sapi, penjualan dan pembelian sapi. Tujuan khusus kegiatan IbM adalah : (1) pengembangan biogas ternak sapi guna meningkatkan kemandirian kelompok peternak sapi masyarakat Kedopok kec. Kedopok Probolinggo. (2) Meningkatkan pengetahuan kelompok peternak sapi dalam mengelola biogas kotoran ternak. Hasil yang dicapai : (1) Tersedianya peralatan berupa instalasi biogas. (2) Terlaksananya pelatihan biogas dan pupuk cair (3) Tersedianya kompor biogas. Dengan mengadakan pelatihan dan pendampingan dalam hal : (1) Membangun instalasi biogas dengan bahan kotoran sapi sebagai sumber energi panas. (2) Pelatihan dan pendampingan dalam pemanfaatan instalasi biogas. (3) Melakukan pelatihan dalam membuat pupuk cair.
\end{abstract}

Kata kunci : Biogas, Probolinggo, pupuk cair, kelompok tani, sapi

\section{PENDAHULUAN}

\subsection{Latar Belakang}

Warga kelurahan Kedopok kec. Kedopok Probolinggo telah lama membudidayakan ternak sapi potong yang dilakukan secara berkelompok. Keberadaan kelompok peternak sapi ini telah mendapatkan dukungan usaha dari dinas peternakan setempat dan pemda Probolinggo namun dirasakan peternak masih kurang karena beberapa sarana penting belum dimiliki diantaranya instalasi biogas.

Pekerjaan utama dari peternak adalah petani atau buruh tani dengan pekerjaan sampingan sebagai peternak sapi. Rata-rata tiap peternak memiliki 2-3 ekor sapi yang dikumpulkan jadi 1 kandang milik bersama dan dikelola 
bersama baik masalah pakan, pengelolaan kandang, bibit sapi, penjualan dan pembelian sapi.

Kelompok peternak mitra adalah : kelompok peternak sapi potong beranggotakan 11 orang dan masing-masing petani memiliki 2-3 ekor sapi yang dikelompokkan dan ditaruh dalam satu kandang bersifat komunal (milik bersama). Satu kandang berisi 14 ekor sapi.

Mitra kegiatan adalah kelompok peternak sapi Bumi Karomah 1 dan Bumi Karomah 2. Produksi yang dihasilkan adalah : sapi, pupuk organik dari limbah sapi dengan kapasitas produksi perhari 2,8 ton / hari (basah) yang dijual ke pemilik tanaman yang membutuhkan pupuk kandang.

Aspek manajemen dalam pengelolaan ternak sapi diringkas sebagai berikut :

1 Sapi dibeli dengan biaya ditanggung anggota sendiri-sendiri.

2 Sapi masing-masing anggota dikandangkan bersama dalam 1 kelompok dan diatur pengelolaannya oleh ketua kelompok.

3 Penjualan sapi dilakukan sendiri oleh masing-masing peternak.

4 Pupuk organik dibeli oleh pengusaha pupuk organik yang dibeli secara borongan

5 Pupuk organik sebagian dimanfaatkan untuk memupuk tanaman pakan sapi dengan sistem terpadu.

\subsection{Permasalahan Mitra}

Permasalahan yang telah disepakati dengan mitra secara ringkas dapat di ringkas sebagai berikut

1. Kotoran sapi menimbulkan bau tak sedap saat dijadikan pupuk organik.

2. Belum mengenal pengelolaan instalasi biogas

3. Belum bisa membuat pupuk cair.

\section{TARGET DAN LUARAN}

Kegiatan IbM di desa Kedopok kec. Kedopok menjadikan target kegiatan adalah : Kelompok UKM peternak sapi potong di Rt05/RW2 (Bumi Karomah 1) dan RT08/RW3 (Bumi Karomah 2) Kel Kedopok.

Luaran kegiatan :

1 Terbangunnya instalasi biogas

2 Terlaksananya pelatihan pengoperasian biogas

3 Terlaksananya pelatihan pupuk cair.

\section{METODE PELAKSANAAN}

(1) Metode yang dilaksanakan dalam pelaksanaan pengabdian adalah sebagai berikut :Tim pengabdi bersama dengan mitra membangun instalasi biogas yang nantinya digunakan sebagi sumber panas kompor dan tempat membuat pupuk cair.

(2) Setelah instalasi terbangun maka akan dilaksanakan pemasukan kotoran ke dalam digester dan bersama mitra akan dilakukan pengujian kinerja instalasi biogas tersebut. 
(3) Jika telah dapat bekerja dengan sempurna maka pemanfaatannya akan dimonitor oleh tim pengabdi.

(4) Melakukan pelatihan dalam membuat pupuk cair.

Prosedur kerja yang akan diterapkan berupa ;

- Sosialisasi kegiatan ke mitra UKM,

- pembangunan instalasi biogas dan pelatihan biogas

- pengujian instalasi biogas dilanjutkan dengan pendampingan pemakaian instalasi biogas ke mitra

- pemberian pelatihan perawatan dan pengoperasiannya ke UKM Mitra.

- Pelatihan pembuatan pupuk cair.

- Evaluasi kegiatan yang dilakukan antara tim pengabdi PT bersama Mitra UKM.

Partisipasi mitra UKM dalam kegiatan adalah :

1. Menyediakan sebagian peralatan dan bahan yang diperlukan selama kegiatan.

2. Menyediakan bantuan tenaga kerja selama kegiatan.

Menyediakan tempat tinggal untuk tim pengabdi.

\section{HASIL DAN PEMBAHASAN}

1. hasil yang dicapai dalam kegiatan berupa:

2. Sosialisasi dan koordinasi pelaksanaan dengan mitra dilaksanakan sebagai upaya untuk menyebarluaskan keberadaan kegiatan ke masyarakat serta mengadakan sinkronisasi pelaksanaan kegiatan agar selaras dengan kebutuhan masyarakat.

3. Membangun lubang instalasi biogas. Kegiatan ini dilaksanakan untuk membuat pondasi dan ruang bagi instalasi biogas.

4. Membangun digester. Pembangunan digester dilaksanakan setelah lubang instalasi telah selesai dan layak digunakan.

5. Membangun lubang input, output dan oksidasi sebagai kelengkapan instalasi biogas.

6. Mengisi biogas dengan kotoran sapi hingga penuh dan mengecek kebocoran.

7. Menguji biogas serta api yang muncul di kompor biogas.

8. Melakukan pelatihan pupuk cair, pemberian modul kegiatan.

9. Melakukan pendampingan terhadap penggunaan instalasi biogas. Mengevaluasi kegiatan bersama mitra.

\section{KESIMPULAN DAN SARAN}

Kesimpulan :

1. Pelaksanaan kegiatan IbM dapat diterima masyarakat sebagai sarana untuk mengembangkan lingkungan terutama yang berkaitan dengan kotoran sapi dan energi alternatif.

2. Masyarakat dapat memperoleh penghasilan tambahan dengan menjual pupuk cair dan padat serta dapat turut menjaga kebersihan lingkungan 
Saran :

Masyarakat mitra masih perlu dibantu dalam mengembangkan usaha sapi serta hal-hal terkait.

\section{DAFTAR PUSTAKA}

Rarindo, Hari. 2011, Pembuatan Kompos, Diktat Kuliah : Univ. Nusa Cendana Simamora, Suhut, Membuat biogas pengganti bahan bakar minyak dan gas dari kotoran ternak, 2006, PT Agromedia Pustaka, Depok

Wahyuni, Sri, Biogas, 2008, Penebar Swadaya, Jakarta 